\title{
CORPORATE SOCIAL RESPONSIBILITY (CSR) APPLICATION OF PT. SIDO MUNCUL, TBK FOR IMPROVING COMMUNITY WELFARE IN EDUCATION
}

\author{
Putri Ayu Tirta Wangi, Setyo Riyanto, Luthfita Ayu Diarta \\ Universitas Mercu Buana, Jakarta, Indonesia \\ Email: 55120010023@student.mercubuana.ac.id, setyo.riyanto@.mercubuana.ac.id, \\ 55120010014@student.mercubuana.ac.id
}

\begin{abstract}
Corporate Social Responsibility (CSR) is an awareness and understanding of the company that is obtained directly or indirectly as one of the important things to be maximized because of the great reputation benefits obtained from the company's CSR activities. CSR is a business commitment so that companies act ethically in running operations legally and contribute to improving the welfare of company employees, local communities, and the wider community. In the literature study, it was found that the benefits will be obtained for the company and the surrounding community.
\end{abstract}

Keywords: corporate responsibility; csr; community welfare

\section{Introduction}

At present it has become a global trend, namely the increasing global public concern about environmentally friendly products, this certainly raises the company's concern so that it is not only business-oriented but also ensures that the company continues to operate in a sustainable manner and remains positioned as part of the community and the environment around (Adrian Sutedi, 2015).

PT. Sido Muncul, who is a well-known herbal medicine producer in Indonesia, is also aware of the Corporate Social Responsibility program to carry out social responsibility in the form of assistance to improve the welfare of the environment and the community around the company which later with this program can improve the company's image in the view of the wider community. In addition, the results of the assistance program run by PT. Sido Appears if the program is successful and runs well, the community will think that PT. Sido Muncul is considered to be a company that is responsive to the community.

Corporate Social Responsibility makes the strength to protect the world still better when it comes to managing the activation it looks bad on. With this in mind, at the end of the day the world will still be able to keep track of how to make it appear to be so good (AS Utomo, 2017).

Corporate social responsibility has been strictly regulated in Indonesia, namely in Law number 40 of 2007 concerning Limited Liability Companies, Law Number 25 of 2007 concerning investment and regulation of the state minister for state-owned

\begin{tabular}{ll}
\hline How to cite: & Wangi, Putri Ayu Tirta, Setyo Riyanto, Luthfita Ayu Diarta (2021) Corporate Social Responsibility \\
& (Csr) Application Of Pt. Sido Muncul, Tbk For Improving Community Welfare In Education, (3)6. \\
& https://doi.org/10.36418/syntax-idea.v3i6.1278 \\
E-ISSN: & $2684-883 X$ \\
Published by: & Ridwan Institute
\end{tabular}


enterprises number per-5 / MBU / 2007 regarding programs partnership state-owned enterprises. with small and environmental business program, especially for SOE PROGRAM. As long as it was held, the results of the research were collected again in No's Draw. 402007 about the territional private vocational school (GB Nayenggita, ST Raharjo, 2019).

Corporate Social Responsibility activity for the community is a process that moves and relates to existing resources in the community, which are currently starting to be maximally utilized by the company (MB S \& ST Raharjo, 2005). As a group that is different from the outside, the main matter of which is to give an accurate view of the internal content (Astri, 2012). To be more precise, before implementing CSR activities, it should be adapted first to the conditions of the local community in order to help implement CSR optimally and minimize so that they are not blamed, especially to advance the quality of life of local communities in Indonesia. With the explanation above, according to the author, the relevant CSR concept is being carried out by PT. Sido Muncul which deals with the community.

\section{Metode Research}

\section{Concept of Corporate Social Responsibility}

According to Tadvada, Corporate Social Responsibility raises no signs of problems that are carried out outside the management of the management and under the law (Tamvada, 2020). The purpose of Tamvada's explanation is that CSR is a social activity carried out by a company not for the purpose of business interests but is related to social activities in helping the community and has been regulated according to the provisions of the law. Meanwhile, according to Jamali \& Mirshak, defining CSR is a concept that has caught the world's attention and gained new resonance in the global economy. Corporate social responsibility has been in high demand in recent years from the emergence of globalization and international trade which is reflected in increased business trade as well as new complexities and demands for increased transparency and corporate citizenship (Jamali \& Mirshak, 2007).

Corporate Social Responsibility activities are a concept of good and healthy corporate governance so that the behavior of business people has a reference in managing all company stakeholder relationships. This is intended so that the company can fulfill properly in preventing mistakes that are implemented as a strategy and ensure that these mistakes can be prevented and do not have an adverse effect on the environment.

\section{Application of Corporate Social Responsibility}

The implementation of CSR carried out by the company will help increase a good reputation, thereby increasing consumer confidence in the company, whether the products or services it sells. Indirectly, this implementation is very important for companies to increase consumer trust, although it does not happen quickly, but in the long term, the results of this implementation that have been implemented will be very useful to increase consumer confidence (Carroll \& Shabana, 2010). 


\section{Benefits of Corporate Social Responsibility}

The benefits of CSR are also so that companies continue to act ethically in accordance with the regulations that have been implemented by the government to continue to pay attention to the community and the surrounding environment, to build the community's economy so that it will be better so that the welfare of the community will also increase. This is because the economy and welfare are mutually sustainable and have a close relationship (Valentin, 2020).

CSR has the aim of encouraging the business world to be more ethical when carrying out business activities and not to adversely affect society and the environment. That way, in the end the company will survive in a sustainable manner so that it can get good benefits for the economy and social welfare which is the goal of forming the business (Valentin, 2020).

\section{Results and Discussion}

This research has been carried out until the sampling stage and preparation for the manufacture of the medium, so that the data collection technique which is carried out through laboratory tests cannot be carried out. So, to obtain data, it can only be obtained through literature review (Perwita, 2011).

Corporate Social Responsibility assistance program conducted by PT. Sido Muncul is manifested in several programs such as scholarships for outstanding students and students who are less well off financially. The programs run by the company are carried out to help improve the welfare of the community in the field of education, so that students who are less able to get a proper education so that one day they can change the welfare of their families or the surrounding environment (Pratiwi, 2017).

The assistance provided is not only in the form of scholarships, but PT. Sido Muncul also conducts a CSR program in the health sector for students and students who are entitled to receive assistance. One of the health assistance that is obtained is health insurance to ensure the health of the scholarship recipients so that in studying education can be carried out properly in a healthy condition and can follow all the educational processes that have been determined (Hidayanti, 2019). Even the construction of educational facilities is also carried out by PT. Sido Appears in several schools that require renovation funds. Assistance for the construction of this facility aims to ensure that the learning space for students can be fulfilled properly so that the learning process of the students can be fun and safe. The construction of educational facilities is also carried out by company (Karaca, 2020).

Directly related to the concept of CSR, companies must adapt to existing changes to implement appropriate business strategies, but must remain focused on the value of social activities that exist in CSR implementation (H. Aguinis, I. Villamor, 2020).

Corporate Social Responsibility assistance program conducted by PT. Sido Muncul must adjust the interests of the target beneficiaries so that the aid distributed remains optimal. Of course, aid distribution activities must also be right on target by 
paying attention to the implementation of Corporate Social Responsibility in accordance with the stipulated provisions.

\section{Conclusion}

Based on the analysis of the literature that has been conducted, CSR is mandatory because it is regulated in accordance with Law Number 40 of 2007 concerning Limited Liability Companies, Law Number 25 of 2007 concerning Investment, and Regulation of the StateMinister for State-Owned Enterprises Number Per-5 / MBU / 2007 regarding the BUMN Partnership Program with Small Businesses and the Community Development Program, especially for BUMN companies. After that, corporate social responsibility is included again in Law No. 40 of 2007 concerning Limited Liability Companies.

The benefits obtained by PT. Sido Muncul in carrying out Corporate Social Responsibility is that the community will increasingly trust and improve the company's image, the better so that the negative stigma against the company can be lost. It is also hoped that CSR implementation will not only be carried out in the short term, but can be carried out in a sustainable manner so that the benefits of the Corporate Social Responsibility program can help the welfare of education for underprivileged students and students. 
Corporate Social Responsibility (CSR) Application of PT. Sido Muncul, Tbk

\section{BIBLIOGRAFI}

Adrian Sutedi, S. H. (2015). Buku pintar hukum perseroan terbatas. RAIH ASA Sukses. Google Scholar

AS Utomo. (2017). The Effect Of Corporate Social Responsibility And Corporate Governance On Financial Performance And Its Implications On Share Prices Of Manufacturing Companies That Go Public In Indonesia Stock Exchange. J. Accounts., 21(3), 425.

Astri. (2012). The use of corporate social responsibility (CSR) to improve the quality of life of Indonesian people. Aspir. J. Masal, 3(2), 151-165.

Carroll, Archie B., \& Shabana, Kareem M. (2010). The business case for corporate social responsibility: A review of concepts, research and practice. International Journal of Management Reviews, 12(1), 85-105. https://doi.org/10.1111/j.14682370.2009.00275.x. Google Scholar

GB Nayenggita, ST Raharjo, \&. R. Resnawaty. (2019). Practices of Corporate Social Responsibility (Csr) in Indonesia. Focus J. Workers., 2(1), 61. Google Scholar

H. Aguinis, I. Villamor, \&. KP Gabriel. (2020). Understanding employee responses to COVID-19: a behavioral corporate social responsibility perspective," Manag. 18(4), 421-438. Google Scholar

Hidayanti, Nanik. (2019). Manajemen dana CSR (corporate social responsibility) di Kecamatan Genuk Kota Semarang. UIN Walisongo. Google Scholar

Jamali, Dima, \& Mirshak, Ramez. (2007). Corporate Social Responsibility (CSR): Theory and practice in a developing country context. Journal of Business Ethics, 72(3), 243-262. https://doi.org/10.1007/s10551-006-9168-4. Google Scholar

Karaca, Ayse Zulal. (2020). Elements that promote interdisciplinarity in higher education environments and campuses. Google Scholar

MB S \& ST Raharjo. (2005). Corporate Social Responsibility (Csr) From Company's Viewpoint. Bussiness and Sociate, 44(4), 415-441. Google Scholar

Perwita, Fajriyah Anjar. (2011). Teknologi ekstraksi daun ungu (Graptophyllum pictum) dalam ethanol $70 \%$ dengan metode perkolasi. Google Scholar

Pratiwi, Shinta Amalia. (2017). Implementasi Kebijakan Tanggung Jawab Sosial Perusahaan (Studi Terhadap Implementasi Peraturan Daerah Nomor 31 Tahun 2012 Tentang Tanggung Jawab Sosial Perusahaan Pada PT Cheil Jedang Indonesia Di Kabupaten Pasuruan). Universitas Brawijaya. Google Scholar

Tamvada, Mallika. (2020). Corporate social responsibility and accountability: a new theoretical foundation for regulating CSR. International Journal of Corporate 
Putri Ayu Tirta Wangi, Setyo Riyanto, Luthfita Ayu Diarta

Social Responsibility, 5, 1-14. Google Scholar

Valentin, Daisy. (2020). Relationship Between Corporate Social Responsibility, Environmental Management, and Profitability. Dissertation. com. Google Scholar

Copyright holder :

Putri Ayu Tirta Wangi, Setyo Riyanto, Luthfita Ayu Diarta (2021)

First publication right :

Jurnal Syntax Idea

This article is licensed under:

(c) $\odot \bigoplus_{\mathrm{BY}} \ominus$ 